\title{
PENERAPAN TEKNOLOGI METODE KANTONG DALAM BUDIDAYA RUMPUT LAUT Eucheuma cottonii GUNA PENINGKATAN PRODUKSI
}

\author{
Nally Y.G.F. Erbabley, ${ }^{1}$ Dominggas M. Kelabora, ${ }^{2}$ dan Martha Rettob ${ }^{3}$ \\ Politeknik Perikanan Negeri Tual, Teknologi Budidaya Perikanan \\ Jl. Langgur-Sathean Km. 6 Kabupaten Maluku Tenggara \\ E-mail : nallyerbabley@gmail.com
}

\begin{abstract}
ABSTRAK. Tujuan pelaksanaan budidaya rumput laut adalah menghasilkan pembudidaya yang mandiri dan mampu berproduksi untuk memenuhi permintaan pasar rumput laut. Dalam memproduksi rumput laut, kendala utama adalah pemangsaan oleh predator ikan sehingga berpengaruh terhadap jumlah produksi yang dihasilkan sehingga penerapan ipteks diperlukan untuk mengatasi kontinuitas produksi rumput laut yang dihasilkan mitra. Target khusus dan luaran dari kegiatan PPM ini adalah dapat mengatasi permasalahan produksi dengan menerapkan metode kantong dalam budidaya untuk menghindari pemangsaan oleh ikan, menggunakan bibit unggul dan menerapkan teknik pengeringan rumput laut yang baik. Metode pelaksanaan PPM untuk mengatasi permasalahan mitra adalah pendampingan berupa penyuluhan dan pelatihan. Hasil pendampingan kegiatan PPM, mitra diharapkan sebagai pembudidaya mandiri yang mampu melakukan budidaya rumput laut dan memiliki kepedulian dan tanggungjawab (sense of belonging) terhadap sumberdaya serta pelestarian sumberdaya yang ada, menghasilkan produk rumput laut yang berkualitas sesuai permintaan pasar dan menjadikan rumput laut sebagai salah satu komoditas andalan untuk meningkat pendapatan. Target luaran tersebut diharapkan mampu berdampak terhadap up-dating ipteks budidaya rumput laut bagi mitra, meningkatkan produktifitas mitra dalam budidaya rumput laut serta pemberdayaan masyarakat dalam peningkatan produktifitas sumberdaya manusia maupun disersivikasi usaha. Luaran kegiatan ini berupa metode budidaya yang dapat dimanfaatkan langsung oleh masyarakat.
\end{abstract}

Kata kunci: budidaya rumput laut; metode kantong; produksi

\section{TECHNOLOGY APPLICATION OF BAG METHOD IN SEAWEED CULTIVATION OF Eucheuma cottonii TO INCREASE IN PRODUCTION}

\begin{abstract}
The purpose of seaweed cultivation is to produce independent farmers who are able to produce to meet the demand of the seaweed market. In producing seaweed, the main obstacle is predation by fish predators that affect the amount of production produced so that the application of science and technology is needed to overcome the continuity of seaweed production produced by partners. Specific targets and outputs of this PPM activity are to be able to overcome production problems by applying the bag method in cultivation to avoid predation by fish, using superior seeds and applying good seaweed drying techniques. The method of implementing PPM to overcome partner problems is mentoring in the form of counseling and training. As a result of the PPM assistance, partners are expected to be independent farmers who are able to do seaweed cultivation and have a sense of belonging to the resources and preservation of existing resources, produce quality seaweed products according to market demand and make seaweed one mainstay commodity to increase income. The target output is expected to be able to have an impact on up-dating science and technology of seaweed cultivation for partners, increase partner productivity in seaweed cultivation and community empowerment in increasing the productivity of human resources and business disertivication. The output of this activity is in the form of cultivation methods that can be utilized directly by the community.
\end{abstract}

Key words: seaweed cultivation; bag method; production

\section{PENDAHULUAN}

\section{Analisis Situasi}

Rumput laut merupakan salah satu komoditas unggulan pada kegiatan revitalisasi perikanan yang prospektif. Saat ini potensi lahan budidaya rumput laut di Indonesia sekitar 1.2 juta ha, namun baru termanfaatkan sebanyak 26,700 ha (2.2\%) dengan total produksi 410.570 ton basah. Budidaya rumput laut tidak memerlukan teknologi yang tinggi tetapi teknologi praktis, investasi cenderung rendah, menyerap tenaga kerja yang cukup banyak dan menghasilkan keuntungan yang cukup besar (Serdiati dkk, 2010).

Rumput laut sebagai komoditas yang prospektif menjadikan usaha budidayanya memiliki peluang dan tantangan untuk memacu paket teknologi bagi pengembangannya secara cepat dan tepat dalam memenuhi permintaan produksi secara kuantitas, kualitas, dan kontinuitas. Indikasi-indikasi visual maupun penentuan kelayakan lahan melalui pengukuran parameter biofisik tidak menjamin keberhasilan budidaya pada suatu areal secara spatio temporal (Nurdjana, 2006).

Meskipun rumput laut telah populer dengan harga yang cukup tinggi, akan tetapi belum mencapai produksi maksimum baik produksi basah, kering maupun kualitas kadar karaginannya. Tidak tercapainya produksi tersebut antara lain di sebabkan karena pembudidaya rumput laut belum mengetahui atau memperhatikan potensi tumbuh dari rumput laut itu sendiri dengan menyesuaikan lokasi budidaya, baik dalam pemakaian bibit dan waktu panen yang belum efektif, serta penggunaan bibit heterogen baik bobot maupun asal thallus, sedangkan pemanenan dalam waktu yang sama. Selanjutnya Carte (1996) mengatakan, penurunan suatu produksi dapat disebabkan antara 
lain oleh lemahnya teknologi budidaya (bibit, metode budidaya, umur panen, dan penanganan pasca panen) dan regulasi pemerintah (penataan ruang dan sumberdaya).

Desa Letvuan, merupakan salah satu desa pesisir yang terletak di pulau Kei Kecil, dan memiliki keanekaragaman pesisir yang cukup tinggi disebabkan desa Letvuan dikelilingi oleh ekosistem mangrove yang merupakan sumber plasma nutfah perairan. Salah satu biota yang dijumpai dan banyak dibudidayakan di desa Letvuan adalah rumput laut jenis Eucheuma cottonii. Rumput laut $E$. cottonii merupakan komoditas unggulan Pemerintah Daerah Kabupaten Maluku Tenggara yang selama ini dikembangkan, karena jenis ini memiliki banyak keunggulan baik sebagai sumber bahan makanan, bahan pembuat kosmetik dan lain sebagainya.

Potensi rumput laut di desa Letvuan tergolong melimpah dan sudah dimanfaatkan oleh masyarakat setempat, namun sejauh ini pemanfaatannya masih belum optimal dilakukan. Untuk memenuhi permintaan pasar, maka persediaan rumput laut harus tetap tersedia, oleh sebab itu agar produksi tetap meningkat maka perlu adanya penanaman yang berkelanjutan yang didukung oleh metode tepat agar hasil panen meningkat. Penanaman rumput laut di desa Letvuan menggunakan metode long line. Hal ini disebabkan karena metode ini mudah diterapkan dan tidak membutuhkan biaya/modal besar serta mudah dikerjaka, lahan yang digunakanpun dapat dioptimalkan. Namun penggunaan metode ini belum sepenuhnya efektif karena pada musim-musim tertentu ketika cuaca ekstrim, terjadi penurunan produksi karena faktor pemangsaan rumput laut oleh ikan, melekatnya lumut pada bagian thalus, serta serangan penyakit iceice yang menyebabkan kerusakan pada thallus akibatnya terjadi penurunan pertumbuhan, produksi menurun bahkan gagal panen. Oleh sebab maka penerapan metode kantong dilakukan sebagai salah satu cara untuk mengantisipasi kegagalan panen petani rumput laut.

Permasalahan yang teridentifikasi pada mitra yaitu :

1. kurangnya ipteks yang dimiliki dalam melakukan usaha budidaya, disebabkan tingkat pendidikan namun kekurangan ini tidak mempengaruhi mitra untuk berusaha.
2. Penggunaan tali long line secara berulang-ulang sehingga mengakibatkan rumput laut yang dihasilkan memiliki mutu yang kurang baik.

3. Perubahan kondisi lingkungan dalam hal ini cuaca sangat mempengaruhi sehingga terjadi gagal panen akibat terserang penyakit ice-ice dan terjadi pemangsaan oleh hama.

4. Tersedianya pabrik pengolahan rumput laut di sekitar lokasi mitra namun mitra belum mampu meningkatkan hasil produksi budidaya rumput laut karena masih menggunakan metode long line, sehingga pada waktu diserang hama menyebabkan produksi menurun dan gagal panen.

Tujuan pelaksanaan utama kegiatan pengabdian pada masyarakat (PPM) adalah menghasilkan pembudidaya mandiri yang mampu berproduksi untuk memenuhi permintaan pasar rumput laut. Oleh sebab itu maka penerapan ipteks dalam hal ini metode budidaya diperlukan untuk mengatasi kontinuitas produksi rumput laut yang dihasilkan mitra. Target khusus dan luaran kegiatan PPM adalah mengatasi permasalahan produksi mitra dengan menerapkan metode kantong dalam budidaya rumput laut untuk menghindari pemangsaan rumput laut dari ikan, menggunakan bibit unggul dalam budidaya rumput laut dan menerapkan teknik pengeringan rumput laut yang baik. Metode pelaksanaan PPM untuk mengatasi permasalahan mitra mencakup aspek produksi berupa penyuluhan dan pelatihan.

\section{METODE}

Sasaran pelaksanaan pengabdian pada masyarakat (PPM) ini adalah kelompok pembudidaya rumput laut di desa Letvuan, yang merupakan mitra kerja kami. Metode yang diterapkan bagi mitra produksi adalah berupa penyuluhan dan pelatihan dilakukan dengan menerapkan metode kantong dan penggunaan bibit unggul serta pemeliharaan rumput laut selama musim tanam untuk memaksimalkan produksi rumput laut. Adapun metode pendekatan, rencana kegiatan dan partisipasi mitra terhadap solusi yang ditawarkan untuk menyelesaikan permasalahan yang telah disepakati pada mitra terlihat pada Tabel 1 .

Tabel 1. Metode Pendekatan, Rencana Kegiatan dan Parti-sipasi Mitra

\begin{tabular}{|c|c|c|c|c|c|}
\hline \multirow[t]{2}{*}{ Prioritas Permasalahan } & \multirow{2}{*}{\multicolumn{2}{|c|}{$\begin{array}{c}\text { Justifikasi Permasalahan } \\
\text { Pendampingan }\end{array}$}} & \multirow{2}{*}{$\begin{array}{c}\text { Metode } \\
\text { Pendekatan } \\
\text { Penyuluhan } \\
\end{array}$} & Rencana Kegiatan & \multirow[t]{2}{*}{$\begin{array}{c}\text { Partisipasi } \\
\text { Mitra }\end{array}$} \\
\hline & & & & Pelatihan & \\
\hline \multicolumn{6}{|c|}{ Produksi } \\
\hline \multirow{4}{*}{$\begin{array}{l}\text { - Kurangnya ipteks } \\
\text { yang dimiliki mitra } \\
\text { dalam melakukan } \\
\text { usaha budidaya }\end{array}$} & $\begin{array}{l}\text { - Transfer dan up-dating } \\
\text { ipteks budidaya rumput laut }\end{array}$ & $\begin{array}{l}\text { - Penggunaan metode kantong } \\
\text { - Pemilihan dan penggunaan } \\
\text { bibit unggul, }\end{array}$ & & & Aktif \\
\hline & - Up-dating informasi : & - harga & & & Aktif \\
\hline & & - kualitas rumput laut & & & Aktif \\
\hline & $\begin{array}{l}\text { - Pengelolaan lingkungan } \\
\text { dan wadah budidaya }\end{array}$ & $\begin{array}{l}\text { - Pemeliharaan dan perawatan } \\
\text { jaring (kantong) } \\
\text { - Pengukuran pertumbuhan } \\
\text { rumput laut dan kualitas air }\end{array}$ & & & Aktif \\
\hline
\end{tabular}




\section{HASIL DAN PEMBAHASAN}

\section{Penerapan Ipteks Pembuatan Kantong Rumput laut}

Ipteks yang diterapkan tim PPM kepada masyarakat khususnya mitra di desa Letvuan adalah penggunaan metode berupa wadah pemeliharaan yang berbentuk kantong atau net basket. Kantong yang diaplikasikan kepada masyarakat adalah bentuk kantong dengan bahan pembuatan yang berbeda, yaitu kantong jaring yang terbuat dari dari bahan polietilen (PE) dan kantong jaring yang terbuat dari tali senar dengan ukuran mata jaring 1 inci.

Pembuatan kantong dilakukan oleh mitra bersamasama dengan tim pengabdi. Teknik pembuatan kantong dilakukan dengan cara terlebih dahulu menggunting jaring PE/tali senar ukuran panjang x lebar $=80 \times 100 \mathrm{~cm}$, selanjutnya dibuat bentuk kantong dengan menggunakan bantuan kawat alumenium. Kawat alumenium di masukan kedalam mata jaring dan membentuk lingkaran, kemudian kedua ujung kawat di ikat dengan menggunakan benang jaring, sehingga membentuk kantong. Bagian bawah kantong di jahit menggunakan benang jaring dengan tujuan agar bibit rumput laut yang diletakan ke dalam jaring tidak jatuh ke dalam laut (Gambar 1).

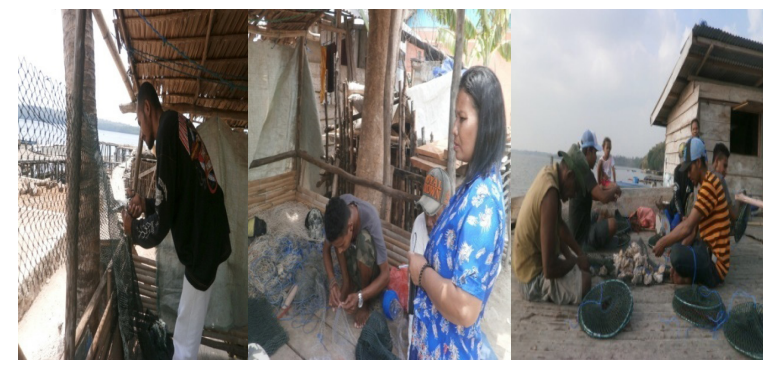

Gambar 1. Pembuatan Kantong/Net Pemeliharaan Rumput Laut

Pembuatan kantong untuk pemeliharaan rumput laut dilakukan dengan beberapa tujuan yaitu agar rumput laut yang dipelihara terhindar dari hama seperti ikan samandar dan penyu, jika terjadi arus yang kuat, thallus yang patah tidak langsung jatuh ke perairan tetapi tetap berada dalam kantong, serta meningkatkan pertumbuhan rumput laut yang dipelihara. Selama masa pemeliharaan dengan menggunakan penerapan metode kantong kepada mitra, hasil yang diperoleh ketika panen meningkat jika dibandingkan dengan menggunakan metode long line biasa yang diterapkan turun temurun dalam masyarakat.

\section{Ipteks Penanaman dan Pemeliharaan Rumput Laut}

Penanaman rumput laut pada akhir bulan Februari 2015. Sebelum penanaman terlebih dahulu mitra diberi penyuluhan dan pelatihan melakukan pemilihan bibit unggul dengan berat awal bibit 100 gr/kantong. Kriteria bibit unggul dengan ciri-ciri sebagai berikut, permukaan thallus licin dan segar, bibit tidak cacat dan tidak terdapat luka pada bagian thallus, tidak teradapat banyak lendir pada permukaan thallus, banyak percabangan dan berwarna cerah (Gambar 2). Tujuan penggunaan bibit unggul agar mitra dapat memilih dan menggunakan bibit yang berkualitas untuk budidaya baik bibit varietas coklat maupun bibit varietas hijau sehingga memperoleh hasil panen maksimal, sekaligus mitra dapat mengetahui pertumbuhan bibit selama 45 hari.

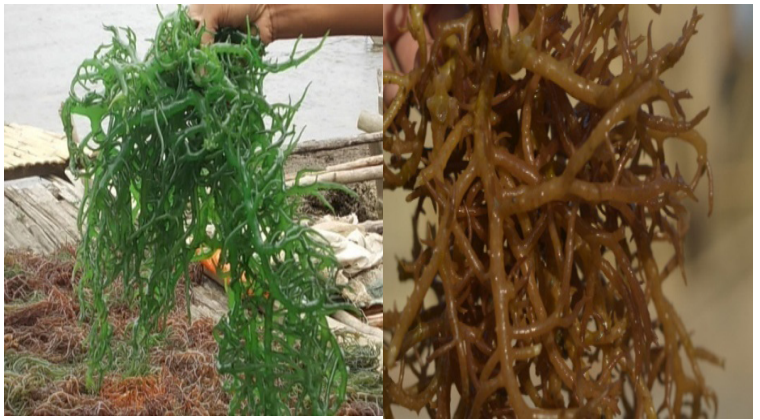

Gambar 2. Bibit Unggul Rumput Laut

Bibit yang memenuhi kriteria dengan ciri-ciri bibit unggul, kemudian dipisahkan untuk selanjutnya dimasukan kedalam kantong/net pemeliharaan untuk diangkut menggunakan speed boat dan diikat pada long line (Gambar 3).

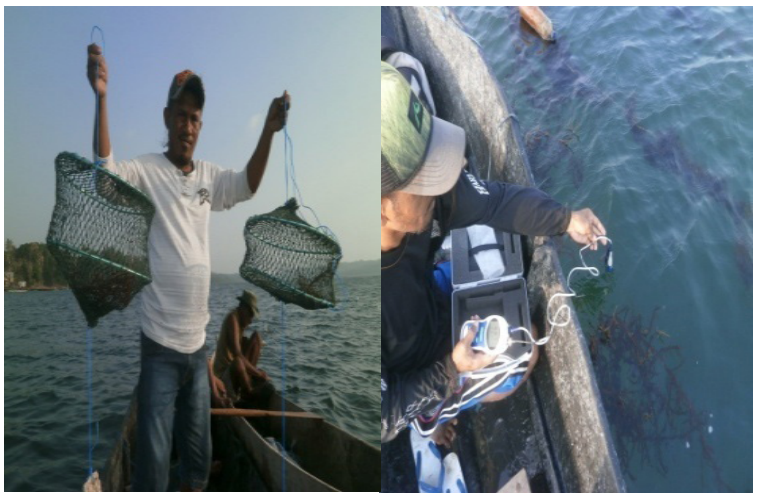

Gambar 3. Metode Budidaya Kantong

\section{Produksi Rumput Laut}

Panen dilakukan setelah rumput laut berumur 45 hari. Panen yang kami lakukan adalah panen secara keseluruhan, dengan cara kantong dlepas dari long linel dan keluarkan rumput laut dari dalam kantong. Rumput laut dimasukan kedalam speed, diangkut kedarat untuk dijemur pada tempat penjemuran atau para-para (Gambar 4).

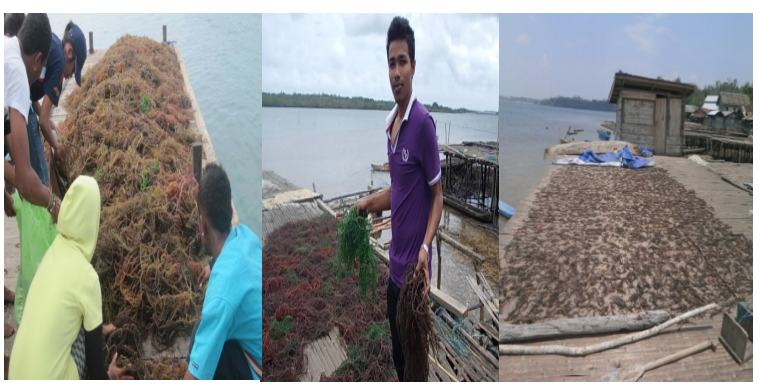

Gambar 4. Hasil Penen Rumput Laut Metode Kantong

Hasil panen rumput laut dengan penggunaan metode kantong yang diterapkan kepada mitra dapat meningkatkan produksi basah lebih tinggi jika dibandingkan dengan 
metode long line biasa (tanpa kantong), seperti terlihat pada Gambar 5 .

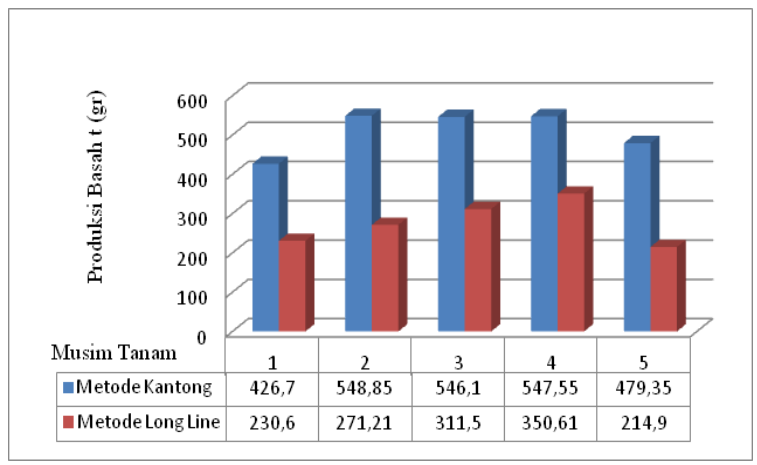

Gambar 5. Produksi Rumput Laut Metode Kantong

Pada pelaksanaannya selain penanaman menggunakan metode kantong juga dilakukan penanaman menggunakan metode long line biasa, hal ini bertujuan untuk mengetahui produksi yang dihasilkan dari kedua metode pada musim tanam periode Februari sampai Juni (5 kali musim tanam). Pada periode musim tanam ke-5 (bulan Juni) baik metode kantong maupun metode long line mengalami penurunan produksi, karena pada periode ini rumput laut yang ditanam terserang penyakit ice-ice dikarenakan hujan terus menerus turun sehingga mempengaruhi kualitas perairan Letvuan. Hasil dari budidaya percontohan sebagian digunakan untuk biaya produksi masa tanam berikutnya, dan sebagian hasil dibagi secara proporsional dengan kelompok tani (pembudidaya). Target luaran dalam pengabdian masyarakat yang dilakukan berupa metode kantong dalam penerapan teknologi budidaya rumput laut di Desa Letvuan Maluku Tenggara untuk meningkatkan produksi rumput laut. Diharapkan luaran yang dihasilkan dari metode ini dapat terus dikembangkan oleh pembudidaya sehingga memberikan dampak positif pada peningkatan produksi sekaligus peningkatan pendapatan masyarkat pembudidaya rumput laut baik bagi kelompok mitra Desa Letvuan maupun bagi masyarakat Maluku Tenggara.

\section{SIMPILAN}

Kesimpulan yang dapat diambil selama pelaksanaan program kegiatan pengabdian masyarakat adalah sebagai berikut; Adanya metode lain yang dapat diterapkan dalam upaya budidaya rumput laut yaitu metode kantong dengan dengan menggunakan bahan jaring dari tali senar (tasi) dan bahan jaring poliethylen (PE); Adanya perbedaan produksi basah yang dihasilkan dari metode long line biasa dengan metode kantong sehingga perlu diterapkan dalam masyarakat sehingga pendapatan mitra pembudidaya meningkat; Penggunaan metode kantong dalam budidaya dapat meningkatkan pertumbuhan rumput laut yang juga berpengaruh terhadap peningkatan produksi basah dan kering; Kondisi perubahan parameter perairan akibat hujan deras mengakibatkan rumput laut mudah terserang penyakit ice-ice akibatnya produksi menurun.

\section{UCAPAN TERIMA KASIH}

Kepada Direktorat Perguruan Tinggi melalui Program Hibah Kompetitif Pengabdian Pada Masyarakat 2014.

\section{DAFTAR PUSTAKA}

Anonimous. (1992). Petunjuk Teknis Budidaya Rumput Laut. Puslitbang Perikanan. Balai Penelitian dan Pengembangan Pertanian Jakarta.

Anonimous. (2004). Budidaya, Pengelolaan dan Pemasaran Rumput laut. Puslitbang Perikanan. Balai Penelitian dan Pengembangan Pertanian Jakarta.

Aslan. L.M. (1998). Budidaya Rumput laut. Kanisius Yogyakarta.

Atmadja. (1996). Pengenalan Jenis-Jenis Rumput Laut Indonesia. Puslitbang Oseanologi - LIPI, Jakarta.

Carte BK. (1996). Biomedical Potensial Of Marine Natural Products. Bioscience 46 : 271-286.

Indriani H \& E. Sumiarsih. (1999). Budidaya, Pengelolaan dan Pemasaran Rumput Laut. PT. Penebar Swadaya, Depok.

Jones AB. Preston, NP \& Dennison WC. 2003. The Efficiency and Condition of Oyster and Macroalgae Used as Biological Filters of Shrimp Pond Effluent. Aquacultur 33 : 1-9.

Kadi A \& Atmadja WS. 1988. Rumput Laut (Alga). Jenis, Reproduksi, Produksi, Budidaya dan Pasca Panen. Proyek Studi Potensi Sumberdaya Alam Indonesia. Pusat Penelitian dan Pengembangan Oseanologi. LIPI Jakarta.

Lee TM., Chang, YC. \& Lin, YH. 1999. Differences in Physyologycal Responses Between Winter and Summer (Gracillaria) Tenuistipitaa to Varying Temperatur. Bot. Bull. Acad. Sin 49:93 - 100.

Nasution MH. (2005). Patogenitas Beberapa Isolat Bakteri Terhadap Rumput Laut Kappaphycus alvarezii di Desa Bantenan-Tumbak Kecamatan Belang Provinsi Sulawesi Utara. Program Pasca sarjana IPB Bogor.

Nontji A. (1987). Fotosintesis dan Fitoplankton Laut. Tinjauan Fisiologis dan Ekologis. Fakultas Pasca sarjana IPB Bogor.

Nurdjana, M.L. (2005). Iklim usaha yang kondusif bagi pengembangan akuakultur di Indonesia. Disampaikan pada acara Konfrensi Nasional Akuakultur di Makassar, 23 - 25 November 2005. 
Kerjasama Masyarakat Akuakultur Indonesia, Balai Riset Perikanan Budidaya Air Payau dan Balai Besar Perikanan Budidaya Laut. Makassar, 25 hal.

Nurdjana, M.L. (2006). Pengembangan budi daya rumput laut di Indoesia, dalam Diseminasi Teknologi dan Temu Bisnis Rumput Laut, Makassar 11 September 2006. Badan Riset Kelautan dan Perikanan. Departemen Kelautan dan Perikanan, hal. 1 - 35 .

Pratiwi E. \& W. Ismail. (2004). Perkembangan budi daya rumput laut di Pulau Pari. Warta Penelitian Perikanan Indonesia, 10, (2). Hal. 11-15.

Pong-Masak, P. R. \& Muh. Tjaronge. (2008). Hubungan kandungan Nitrogen dan Phosfor dalam perairan terhadap kandungannya dalam tallus rumput laut, Kappaphycus alvarezii pada lokasi berbeda di Sulawesi Selatan. Prosiding Seminar Nasional Perikanan dan Kelautan, Bidang Budidaya Perikanan. Fakultas Perikanan dan Ilmu Kelautan. Universitas Brawijaya. Malang, 3 November 2008. Hal. I.18 - I. 25.

Rorrer GL and Cheney DP. 2004. Bioproses Enginnering of Cell and Tissue Cultures for Marine Seaweeds. Aquacultural Enginnering.

Serdiati N, Irawati \& Mei Widiastuti. (2010). Pertumbuhan dan Produksi Rumput Laut Eucheuma cottonii
Pada Kedalaman Yang Berbeda. Media Litbang Silteng III,(2). 21-26.

Sulistijo. (1996). Perkembangan Budidaya Rumput laut di Indonesia Dalam Pengenalan Jenis-Jenis Rumput Laut. Puslitbang Oseanologi LIPI Jakarta.

Soesilo, I. \& Budiman. (2002). Iptek untuk laut Indonesia. (Penyunting: Aryo Hanggono). Lembaga Informasi dan Study Pembangunan Indonesia (LISPI). Jakarta. $186 \mathrm{p}$.

Sulistijo. (2002). Penelitian Budidaya Rumput laut (Alga makro/Seaweeds) di Indonesia. Pidato Pengukuhan Ahli Peneliti Utama Bidang Akuakultur. Pusat Penelitian Oseanografi Lembaga Ilmu Pengetahuan Indonesia, Jakarta.

Tjaronge, M. \& P.R. Pong-Masak. (2005). Karakteristik kandungan nutrien lingkungan perairan bagi pertumbuhan rumput laut, Eucheuma sp pada lokasi berbeda di Sulawesi Selatan. Laporan Penelitian Balai Riset Perikanan Budidaya Air Payau. Maros, 12 hal.

Zatnika A \& Angkasa WI. (1994). Teknologi Budidaya Rumput Laut. Dalam Seminar Laut Nasional II. Kantor Mentri Negara KLH, Laboratorium Ilmu-Ilmu Kelautan UI IPB dan Ikatan Sarjana Oseanologi Indonesia (ISOI). 